\title{
RAW MATERIAL INVENTORY PLANNING OF PATIENT MENU USING MATERIAL REQUIREMENT PLANNING (MRP) IN RSIA KENDANGSARI MERR SURABAYA
}

\author{
Dewi Sri \\ Health Policy and Administration, Public Health, \\ University of Airlangga \\ Email:dewisri5690@gmail.com
}

\section{ARTICLE HISTORY}

Received:

10 January 2020

Revised

16 November 2020

Accepted:

28 December 2020

Online available:

06 May 2021

Keywords:

Inventory,

Forcasting,

Material

Requirements

Planning

\section{ABSTRACT}

Introduction: Material Requirement Planning (MRP) is a technique or a logical procedure to translate the Master Production Schedule (MPS) of the finished goods or end item into the net requirements for some of the components needed to implement the MPS. MRP is used to determine the amount of material needs to support the Master Production Schedule and when the material needs to be scheduled.

Methods: The study is conducted on 13 August 2018 until 12 September 2018 at the installation Nutrition RSIA Kendangsari Merr Surabaya. Collecting data in this study using several methods, including: observation- This stage is conducted in all parts related to the object of study, starting from the Purchase Order (PO) by a head cook up to raw material stored in the storage, discussion- author interviews and collects data to communicate and discuss with the respondents. Respondents in this study are the head of the nutrition unit and head cook of RSIA who have the authority doing the purchasing.

Results: Planning of procurement of raw materials to the menu rawon in RSIA can use the Exponential Smoothing method. The discussion has compared two methods of forecasting and the results are consistent with the demand's patterns of Simple Moving Average method, Exponential Smothing. Forecasting has the lowest error rate by using Exponential Smoothing. The second conclusion is a technique of determining the appropriate Material Requirement Planning in raw material procurement to menu rawon in RSIA is using Lot for Lot. 


\section{INTRODUCTION}

The hospital is a health care institution that organizes personal health services in plenary that provides inpatient, outpatient, and emergency services, Act No. 44 of 2009, while WHO defines THAT Hospitals as social organizations which have integrated functions to provide complete health care for the community including promotive services (increase), prevention, curative (healing) and rehabilitative (repair). Specified in Law No. 44 of 2009 Article 4 and 5 of the Hospital stated that the hospital has a duty to provide personal health services in plenary, namely: Standard hospital services, provides criteria regarding the type of services related primarily to the structure and process of hospital services. These criteria must be fulfilled by all hospitals or in other words when the criteria can be fulfilled by a hospital, the hospital service quality can be accounted for. One of the efforts of health services in hospitals is the implementation of nutrition services integrated with other services in the hospital. Nutrition services at the hospital are another factor on improving the nutritional status of patients. Currently nutritional services started become a benchmark of service quality in the hospital because the food is a basic human need and believed to be a deterrent and help cure a disease.

The purpose of nutrition services at the hospital is creating a system of nutritional services concerning the aspect of nutrition and disease. Part of the health care in order to improve and develop the quality of nutrition services at the hospital ( $\mathrm{MOH}, 2005)$. To achieve these objectives, it is essential implemented the management of the food is good, resulting in food quality. Consuming food means also consume nutrients. One of the factors causing malnutrition is the lack of intake of essential nutrients because of food consumed is not enough, both quality and quantity. When these conditions occur in patients who are hospitalized, then in addition will reduce the nutritional status of patients also prolong the patient and increases maintenance costs.

To anticipate the necessary methods of planning and control of food supplies. The main objective of planning and inventory control system is to get the right material with the right amount and available at the right time to meet production needs.

RSIA Kendangsari Merr Surabaya is one private mother and child hospital in Surabaya, which provides complete health care for the needs of mothers and children. In carrying out its functions, RSIA Kendangsari Merr Surabaya provide comprehensive health care for mothers and children. Health services are provided prima and comprehensive for patients, their families, and providers. In the operation of eating for the patient, this time RSIA Kendangsari Merr Surabaya planning and controlling food ingredients to the patient does not based on the methods that is standard only based on conventional calculations that Officers cook recapitulation order needs groceries for two days before the cycle goes the way: a standard portion of $x$ number of patients on the day of booking and then the results of calculation plus 3 serving as a buffer stock. This often leads to excess or 
shortages of raw materials that can cause delays in the production process to meet the needs of the patient. To help solve these problems, especially the problem of raw material requirements planning, it should develope a system Material Requirements Planning (MRP). By implementing such a system, it is expected to meet raw material requirements can be done right, and the determination of inventory cost can be defined as optimal as possible. Based on these descriptions, the authors will perform an analysis to provide advice on planning a patient's raw material inventory menu.

Based on this background, the authors formulate the problem in this study as follows: one: how to plan the raw material needs of the patient menu. The boundary problem in this study is the object of study devoted to the planning of patient navigation stocks of raw materials, the time period used for the research is the data in October 2014 - September 2015, and the method used is MRP (Material Requirement Planning). This study aims to determine the estimated needs of the patient menu of raw materials to meet production needs, especially for necessities. In addition, to obtain the most efficient MRP system to be applied in planning the menu supplies the raw material needs of patients.

\section{LITERATURE REVIEW}

Inventory as the company's assets, has an important role in business operations. In the factory (manufacturing), supplies may consist of: supply of raw materials, auxiliary materials, WIP (work in process), finished goods and spare parts inventory. In an organization, such as hospitals, beauty salons, hotels, most have the inventory to be able to provide the best service to customers. Retail stores such as supermarkets, have to maintain inventories of finished goods, in order to meet customer demand. So stock is very important both for companies that produce goods or services.

\section{Functions and Objectives Inventory}

There are three reasons for the need of inventory for companies and organizations (Yamit, 2002):

1. Due to the uncertainty of demand (demand suddenly)

2. Due to the uncertainty of supply from suppliers

3. Due to the uncertainty of a grace period of booking.

Facing three elements of this uncertainty, the company must make a proactive inventory management, in the sense of being able to anticipate the circumstances and challenges faced in inventory management.

Inventory management challenges can come from outside or from within the company. These challenges are closely related to the purpose of the inventory, namely:

1. To provide the best service to the customer

2. To facilitate the production process 
3. To anticipate the possibility of (stockout) inventory shortages

4. For menghadapi price fluctuations

Achievement of these objectives, the consequences for the company, which must bear the costs and risks associated with inventory decisions. Therefore, the final goal of inventory management is to make decisions inventory levels, which balances the purpose of the inventory with the costs incurred. In other words, the final goal of inventory management is to minimize the total cost of the changes in inventory levels.

\section{Forecasting}

According Gitosudarmo (2002) forecasting (forecasting) is an attempt by the company to be able to predict, predict the future state of the product by finding out the limits the uncertainty of the future of the company. Forecasting (forecasting) is an estimate of the situation in the future by using the data in the past (Adam Jr \& Ebert, 2002).

According Lindawati (2013), the forecasting system, the use of forecasting models will give different forecasting value and the degree of forecast error is different. One of the art in forecasting is selecting the best forecasting model that is able to identify and respond to patterns of historical activity data. In general, forecasting models can be grouped into two main groups, namely the qualitative and quantitative methods. Qualitative method which consists of the Delphi Method, Technology Comparison Method and Method of Subjective Curve Fitting. Meanwhile, Quantitative Methods and consists of Univariate (Time Series), Last Period Demand, Simple Average, Moving Average, Single / Double Exp Smoothing, multiplicative Winter / decomposition, Casual (Structural), and Multivariable regression.

In this research, forecasting will be tested using two methods of forecasting, the method of Simple Moving Average, Exponential Smoothing which will be described below:

a. Moving Average Method Single (Single Moving Averages).

According to Nasution (2003) Single Moving Averages obtained by averaging the request based on some past data up to date.

b. Exponential Smoothing Methods

According to Render \& Heizer (2005) is the exponential smoothing forecasting techniques moving average weighted where data were weighted by an exponential function.

\section{Measurement Errors Forecasting}

According Lindawati (2003), in forecasting there are a number indicators to measure the accuracy of forecasting, but is most often done is MAD (Mean Absolute Demand $=$ median absolute deviation), MAPE (Mean Absolute Percentage Error = average percentage absolute error), MSE (Mean Absolute Error = Average ata squared error). Forecasting accuracy will be higher when the value of MAD, MAPE and MSE getting 
smaller. According to Hartini (2006) notion of MAD, MAPE and MSE, is MAD which is the average absolute error for a certain period regardless of whether the result of forecasting a bigger or smaller than reality. le the percentage error MAPE forecasting results against the actual demand for a certain period that will release information error percentage is too high or too low.

Measurement of forecasting error can be calculated by the formula following:

1. MAD (Mean Absolute Deviation) is a measure of forecasting accuracy by averaging the forecasting error (in absolute value)

$$
M A D=\sum\left[\frac{A t-\not t}{n}\right]
$$

At $=$ Actual Demand in period $t$

$\mathrm{Ft}=$ Forecasting Demand in period $\mathrm{t}$

$\mathrm{N}=$ Number of the forecast period involved

2. MSE (Mean Squared Error) is an alternative method of evaluating a forecasting technique. Any errors or residuals squared, then summed and divided by the total number of observations. The equation is:

$$
M F E=\sum \frac{(A t-F t)}{n}
$$

Information :

At $=$ Actual Demand in period $t$

$\mathrm{Ft}=$ Forecasting Demand in period $\mathrm{t}$

$\mathrm{N}=$ Number of the forecast period involved

3. The Mean Absolute Percentage Error (MAPE) can be calculated using the absolute error in each period divided by the value of the real observation for that period. Then, averaging the absolute percentage error. This approach is useful when a large size or forecast variables are important in evaluating the accuracy of the forecast. MAPE indicates how big a mistake in divination than the real value in the series. MAPE can be calculated with the following formula:

$$
M A P E=\left(\frac{100}{n}\right) \sum \frac{(A t-F t)}{n}
$$

Information :

At $=$ Actual Demand in period $t$

$\mathrm{Ft}=$ Forecasting Demand in period $\mathrm{t}$

$\mathrm{N}=$ Number of the forecast period involved

\section{Material Requirement Planning}


Material Requirements Planning (MRP) can be defined a technique or set of systematic procedures in the determination of the quantity and time in the process control needs of the components of demand were interrelated (Dependent demand items) (Gaspersz, 2012).

"Material Requirements Planning is a time phased planning technique that calculates the priority requirements and schedules material supply to meet demand across all products and parts in one or more plants" (V Moustakis, 2013).

\section{The aim of material requirements planning}

MRP systems are prepared to answer the question of when, how much, and what are the raw materials needed accurately and efficiently (Moustakis, 2010). MRP purpose, among others:

1. Stock (inventory): order appropriately, either in the form of the item, quantity, and timing;

2. Priority scheduling: ordering goods item needs precisely when it is needed (right due date) and keep the due date will not be missed;

3. The capacity of the plant (capacity plan): create imposition plans prompt and full employment.

\section{MRP System Information Flow}

The flow of information within the MRP system where the MRP process requires three resources, namely:

1. Masters Production Schedule / Master Production Schedule

MPS (Masters Production Schedule) is one of the three main inputs in the MRP containing end product of what is planned for the production company, how quantitative required, and when the product will be produced. (Jha, 2012: 2378-2379)

According Gaspersz (2005: 177) MPS is a definitive statement about what the final product the company plans to produce, what quantity is required, at the time when it is needed, and when the product will be produced.

The production schedule is a summary of the finished product production schedule for the coming period were designed based on customer orders or forecast demand. MRP system assumes that the orders were recorded in the production schedule is uncertain, although only a forecast.

2. Bill Of Materials (BOM)

BOM (Bill Of Materials) is a list of all materials, parts, and subassemblies, as well as the quantity of each required to produce one unit of product or parent assembly. MRP uses the BOM as a base for the calculation of the amount of each material required for any period of time. (Gaspersz, 2005: 178)

According to Jha (2012: 2379) contains a list of all assemblies, subassemblies, parts, and raw materials needed to produce one unit of finished goods. BOM data is 
often called Product structure because it shows how a product is put together. It contains information to identify each item and the quantity used. BOM is a list of all materials, parts, sub-assemblies, as well as the quantity of each required to produce one unit.

3. Item Master

Item Master is a file that contains status information about the materials, parts, subassemblies, and products showing the quantity on-hand, the quantity allocated (allocated quantity), the waiting time planned (planned lead time), lot size (lot size), safety stock, lot sizing criteria, tolerances for scrap or results, and other important information relating to an item

\section{Stages of Preparation MRP}

Basic stages in the preparation of the MRP process is as follows (Nasution \& Natigor, 2004):

1. Netting (Net requirements) is a calculation process to establish the sheer number of net requirements for each period during the planning horizon which amount represents the difference between the gross requirements with the state of inventories (which in stock and on order).

2. Lotting is determining lot size (number of orders) which ensures that all needs will be met, the order will be scheduled for completion at the beginning of the period in which there is a positive net requirements.

3. offsetting (Ordering plan) is one step in MRP to determine the right time to plan to meet the needs reservations clean. Booking plan obtained by combining the initial time of availability of the lot size (lot size) desired by the amount of time ancang- square. Square off time is equal to the time when goods are ordered or manufactured start until the goods are ready for use.

4. Exploding a process of calculating the gross requirements for the level (level) which is lower in a structure based on the products and ordering plan.

According to Hartini (2006), four basic steps in the processing of MRP is as follows: One. Netting (net requirement calculations) Requirement clean (NR) was calculated as the value of the gross requirements (GR) minus the reception schedule (SR) minus inventory on hand $(\mathrm{OH})$. Net requirement is considered zero when NR is smaller than or equal to zero. Two. Lotting (determining the size of the lot), this step is to determine the optimal size of individual orders based on the results of the calculation of net requirements. This step is performed using a technique lotting / lot sizing right. The parameters used mainly usually is the cost savings and the cost of the message. Three. Offsetting (determining the size of booking). This step aims to needs items can be available right at the time it takes to calculate the component procurement lead time.

\section{RESEARCH METHODS}


The study is conducted on 13 August 2018-12 September 2018 at the installation Nutrition RSIA Kendangsari Merr Surabaya. Collecting data in this study using several methods, including:

1. Observation

Collecting data by conducting a careful observation and recording of so-called observation. This stage is carried out in all parts related with the object, starting from the Purchase Order (PO) by a head cook up raw materials kept in storage.

2. Interviews and Discussions

In the interview, the author conducted data collection by communicate and discuss directly with the respondent. Respondents in this study are the head of the nutrition unit and head cook RSIA who have the authority to do the purchasing.

3. Conducting Review of Literature

In conducting the study, so the results obtained can be matched with the expectations, the authors require greater insight related to forecasting and MRP method so that the author will be able to process the data correctly, so will yield accurate analysis.

4. Analysis

Once you have a sufficient theoretical basis and the data obtained from RSIA, authors will begin planning raw material requirements for manufacturing,

\section{RESULT AND ANALYSIS}

Installation Nutrition RSIA Kendangsari Merr has a meal for patient on 11 menus. Cycle menu made for 10 days and added to a cycle of 11 which means that in one month (30 days) applies 3 cycles. When one month is 31 days, then come into force three cycles plus 1 menu for 31. this study will only foreseen needs only one patient meal menu, selecting menu based on the menu that has the highest total raw material prices. In planning needs required menu usage data or data needs of the previous year which will be used as the basis for predicting or forecasting for future needs. Forecasting is a process to recognize patterns of demand (demand pattern) in the past to forecast the demand in the future.

Table 1

Data needs one patient meal menu August 2017- September 2018

\begin{tabular}{cc}
\hline Month & The number of requests (portion) \\
\hline August 2017 & 32 \\
September 2017 & 37 \\
October 2017 & 35 \\
November 2017 & 32
\end{tabular}




$\begin{array}{cc}\text { December } 2017 & 50 \\ \text { January } 2018 & 36 \\ \text { February } 2018 & 36 \\ \text { March } 2018 & 36 \\ \text { April } 2018 & 36 \\ \text { May 2018 } & 34 \\ \text { June } 2018 & 27 \\ \text { July 2018 } & 28 \\ \text { August 2018 } & 30 \\ \text { September 2018 } & 29\end{array}$

Source: Secondary Data Installation RSIA Nutrition Kendangsari Merr Surabaya in 2017-2018

To recognize the pattern needs of rawon rice menu which is based on the data rawon rice needs in August 2017- September 2018, then the data in the table is created in the form of a graph so that the pattern data needs of rawon rice menu can be formed, which can be used as a basis in determining methods forcasting to forecast demand in the future. Based on data rawon rice needs on month August 2017-September 2018, the data pattern is formed in Figure 1 is a kind of horizontal or constant.

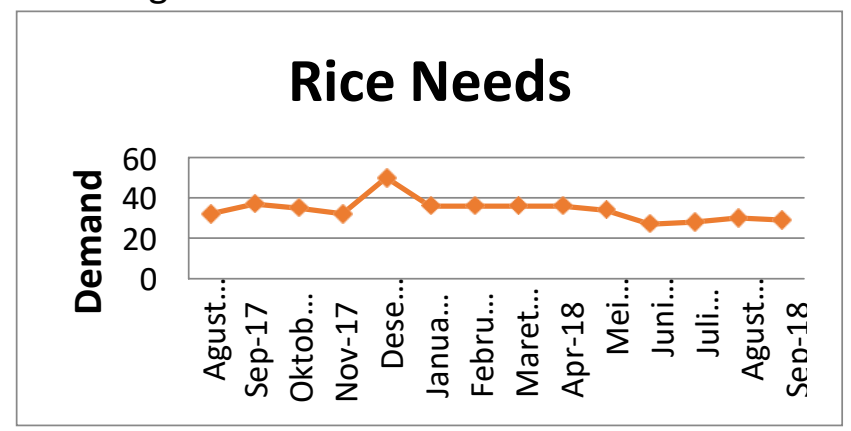

Figure 1

Graphs the rice needs rawon

Based on Figure 1 above can be seen that the data pattern is formed does not have a tendency to rise or fall. Based on the data pattern formed in Figure 14 is a pattern of constant data. Forcasting method in accordance with the pattern of constant data is Moving Average and Exponential Smoothing.

In this study, the results of forecasting using 2 methods stretcher, will be selected one method with the smallest percentage of error. Forecasting results with the smallest error value is what will be used as reference to the manufacture of Master Production Schedule (MPS). In the testing process 2 of this forecasting method, will be used one sample of meat raw material. The raw material is chosen because it is the amount of material the greatest demand among other materials demand.

Below is the result of the calculation of several methods forcasting, then of some forecasting methods will be compared. Some comparative purposesmethod forcasting is to determine method forcasting which best suits the needs of the data pattern rawon rice.Selection methods forcastingwhich will be used based on the value the Mean Absolute Deviation (MAD) or Mean Absolute Percent (MAPE), the smallest. Mean Absolute Deviation is the difference between actual demand and resultsforcasting. Mean 
Absolute Percent obtained from the Mean Absolute Deviation value divided by actual demand and then multiplied by 100. In other words MAPE is a percentage of the value of MAD.

Here is a comparison Standard Error (error value) for methods forcasting Moving Average, Exponential Smoothing.

Table 2

Comparison of Standard Error (error value) for methods forcasting Moving Average, Exponential Smoothing

\begin{tabular}{llll}
\hline \multirow{2}{*}{ Method } & standard Error & & \\
\cline { 2 - 4 } & MAD & MSE & MAPE \\
\hline MA 3 & 4.3 & 36.1 & $12.0 \%$ \\
\hline MA 4 & 5 & 45 & $14 \%$ \\
\hline MA 5 & 3.6 & 19.9 & $11.9 \%$ \\
\hline ES 0.1 & 3.8 & 33.9 & $10.8 \%$ \\
\hline ES 0.2 & 3.4 & 34.5 & $9.8 \%$ \\
\hline ES 0.3 & 3.8 & 34.7 & $10.7 \%$ \\
\hline ES 0.4 & 3.6 & 34.4 & $9.9 \%$ \\
\hline ES 0.5 & 3.6 & 34.5 & $10.0 \%$ \\
\hline
\end{tabular}

Ket:

MAD Mean Absolute Deviation

MSE Mean Squared Error

MAPE Mean Absolute Percent

MA 3 Moving Average with $\mathrm{n}=3$ months

MA $4 \quad$ Moving Average with $n=4$ months

MA $5 \quad$ Moving Average with $\mathrm{n}=5$ months

ES $0.1 \quad$ Exponential Smoothing with $\alpha=0.1$

ES 0.2 Exponential Smoothing with $\alpha=0.2$

ES 0.3 Exponential Smoothing with $\alpha=0.3$

ES $0.4 \quad$ Exponential Smoothing with $\alpha=0.4$

ES $0.5 \quad$ Exponential Smoothing with $\alpha=0.5$

From Table 2 above can be seen that the standard error produced by the methodforcasting Exponential smoothing with a value of $\alpha=0.2$ is smaller than using methods forcasting Moving Average, Thus it can be concluded that the methodforcasting Exponential smoothing more optimally used as a method forcasting for forecasting future rawon rice compared to the method forcasting Moving Average.

This is in line with the results of the study (Anggriana, 2015) After comparing all three methods produced the data that the Exponential Smoothing forecasting method produces a value error (MAPE) the smallest is $43 \%$. Based on the calculation of the rice 
needs rawon using exponential smoothing forecasting method with a value of $\alpha=0.2$ in the table can be obtained forecasting rice rawon in October amounted to 32 servings.

1. Product structure data

Rawon rice products for the structure is as follows:

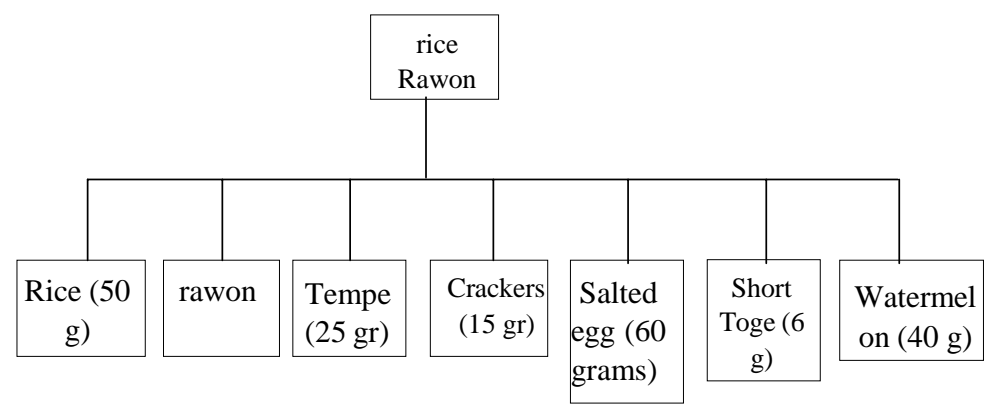

\begin{tabular}{|c|c|c|c|c|c|c|c|c|c|c|c|c|}
\hline $\begin{array}{c}\text { Garlic } \\
(6 \mathrm{~g})\end{array}$ & $\begin{array}{c}\text { Red } \\
\text { Bawan } \\
(7 \mathrm{~g})\end{array}$ & $\begin{array}{l}\text { Turmer } \\
\text { ic }(6 \mathrm{~g})\end{array}$ & $\begin{array}{c}\text { Laos } \\
\text { (11 g) }\end{array}$ & $\begin{array}{l}\text { Sere } \\
(6 \mathrm{~g})\end{array}$ & $\begin{array}{l}\text { Bawan } \\
\text { gprey } \\
(6 \mathrm{~g})\end{array}$ & $\begin{array}{l}\text { Lime } \\
\text { leaves } \\
(6 \mathrm{~g})\end{array}$ & $\begin{array}{c}\text { Kluwek } \\
\text { (25 gr) }\end{array}$ & $\begin{array}{l}\text { Lombo } \\
\text { kmerah } \\
(10 \mathrm{~g})\end{array}$ & $\begin{array}{l}\text { Salt (2 } \\
\text { g) }\end{array}$ & $\begin{array}{c}\text { Cookin } \\
\mathrm{g} \text { oil } \\
(20 \mathrm{~g})\end{array}$ & $\begin{array}{c}\text { Meat } \\
\text { rawis (50 } \\
\mathrm{g})\end{array}$ & $\begin{array}{r}\text { Manisa } \\
(15 \mathrm{gr})\end{array}$ \\
\hline
\end{tabular}

Figure 2

Structure of rice products rawon

This means that to produce one serving of rice rawon needed rice $(50 \mathrm{~g})$, meat rawis (50 g), manisa (15 g), tempeh (25 grams), crackers (15 g), salted egg (60 grams), toge short (6 g), watermelon (40 grams), garlic (6 g), onions (7 g), turmeric (6 g), Laos (11 $\mathrm{g})$, sere (6 g), onions prey ( $6 \mathrm{~g})$, lime leaves $(6 \mathrm{~g})$, beef stew ( $25 \mathrm{~g})$, red chilli (10 grams), salt (2 g) and cooking oil ( $20 \mathrm{~g})$.

\section{Bill of Materials}

Making Bill of Materials(BOM) based on the structure of rice products rawon in the image above. BOM is a translation table of product structure, which gives the following data: the level of each component, the required amount of each component, as well as the source of the component. Making the product structure will be used as a basis to create the BOM. Here is a Bill of Materials rawon rice. 
Jurnal Ekonomi dan Bisnis Airlangga, Vol. 31, No. 1, December - May 2021

Table 3

Bill of Materials rice rawon

\begin{tabular}{clll}
\hline Level component & Component & Amount $(\mathrm{g})$ & Source \\
\hline 0 & rice rawon & 1 serving & For \\
1 & Rice & 50 & Buy \\
1 & rawon & 25 & For \\
1 & Tempe & 60 & Buy \\
1 & Salted egg & 22 & Buy \\
1 & short toge & 40 & Buy \\
1 & Watermelon & 15 & Buy \\
1 & crackers & 6 & Buy \\
2 & Garlic & 7 & Buy \\
2 & Shallot & 6 & Buy \\
2 & onions prey & 6 & Buy \\
2 & Turmeric & 11 & Buy \\
2 & Laos & 6 & Buy \\
2 & Sere & 6 & Buy \\
2 & Lime leaves & 25 & Buy \\
2 & kluwek & 10 & Buy \\
2 & red chilli & 2 & Buy \\
2 & Salt & 20 & Buy \\
2 & Cooking oil & 50 & Buy \\
2 & meat rawis & 15 & Buy \\
2 & Manisa & Buy \\
\hline
\end{tabular}

3. Material production schedule (master production schedule)

Data forecasting results obtained with the exponential smoothing forecasting method with a value of $\alpha=0.2$ which needs rawon rice in October 2018 amounted to 32 servings. Here are the details of the needs of each component of the raw material required to make rice rawon for the month of October 2018.

Table 4

Rawon rice requirement in October 2018

\begin{tabular}{llll}
\hline Material & 1 serving $(\mathrm{g})$ & forcasting & total demand \\
\hline Rice & 50 & 32 & 1600 \\
Tempe & 25 & 32 & 800 \\
Salted egg & 60 & 32 & 1920 \\
short toge & 22 & 32 & 704 \\
Watermelon & 40 & 32 & 1280 \\
crackers & 15 & 32 & 480 \\
Garlic & 6 & 32 & 192 \\
Shallot & 7 & 32 & 224 \\
onions prey & 6 & 32 & 192 \\
Turmeric & 6 & 32 & 192 \\
Laos & 11 & 32 & 352 \\
Sere & 6 & 32 & 192
\end{tabular}




\begin{tabular}{llll} 
Lime leaves & 6 & 32 & 192 \\
kluwek & 25 & 32 & 800 \\
red chilli & 10 & 32 & 320 \\
Salt & 2 & 32 & 64 \\
Cooking oil & 20 & 32 & 640 \\
meat rawis & 50 & 32 & 1600 \\
Manisa & 15 & 32 & 480 \\
\hline
\end{tabular}

According to the table to know the needs of each component of the raw materials required for the manufacture of rice rawon in October 2018. The master production schedule will be made within a period of 10 daily. Data forecasting results needs of each component of raw material for making rice rawon for the month of October 2018 will be divided into 3 periods in 1 month. Here is one example of material requirements planning of raw materials rawis meat.

Table 5

Material Requirement Planning In October 2018

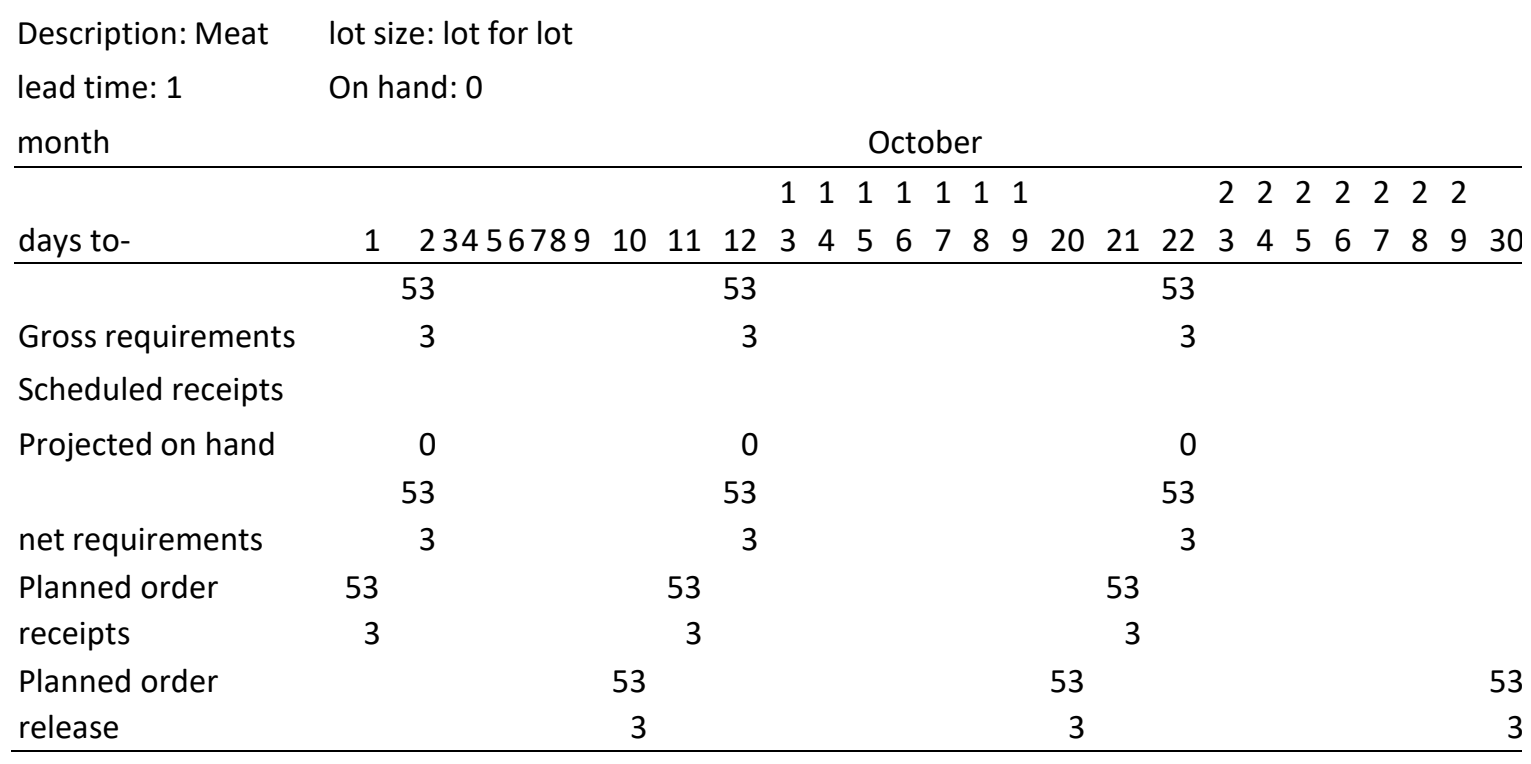

\section{CONCLUSION}

Based on the analysis that has been done in the previous chapter, it can be concluded that the planning of procurement of raw materials to the menu rawon in RSIA can use the Exponential Smoothing method. In the discussion has compared two methods of forecasting in this study are consistent with the patterns the demand of the method of Simple Moving Average, Exponential Smothing. Forecasting has the lowest error rate is by using Exponential Smoothing. Conclusion The second is a technique of determining the 
appropriate Material Requirement Planning in raw material procurement to menu rawon in RSIA is using Lot for Lot.

\section{REFERENCES}

Adam Jr, E. E., \& Ebert, R. J. (2002). Production And Operation Manajemen (5 (ed.)). Prentice Hall Inc.

Gaspersz, V. (2012). Production Planning and Inventory Control berdasarkan pendekatan sistem terintergrasi MRP II dan JIT menuju manufaktur 21. Gramedia Pustaka Utama.

Gitosudarmo, I. (2002). Manajemen Keuangan Edisi 4.

Lindawati. (2013). Perencanaan bahan baku di CV. Soloindo Tama.

Moustakis, V. (2013). Enterprise Resource Planning and Supply Chain Management. Heidelberg: Springer-Verlag.

Moustakis, Vassilis. (2010). Materials Requirements Planning-Manufacturing Resource Planning. Report produced for the EC funded project INNOREGIO. Technical University Of Crete.

Nasution, F., \& Natigor. (2004). Just in Time dan Perkembangannya dalam Perusahaan Industri. Fakultas Ekonomi, Universitas Sumatera Utara.

Render, B., \& Heizer, J. (2005). Operations Management.

Yamit, Z. (2002). Manajemen produksi dan operasi (1st ed.). Fakultas Ekonomi, Universitas Islam Indonesia. 